\title{
High school students' conceptions about learning and instruction: A metaphor analysis
}

\author{
Gokhan Bas ${ }^{1}$ and Zafer Savas Kıvılcım² \\ ${ }^{1}$ Nigde Omer Halisdemir University, Turkey (ORCID: 0000-0002-9755-0003) \\ ${ }^{2}$ Ministry of National Education, Turkey (ORCID: 0000-0002-7056-726X)
}

\begin{abstract}
In this study, we aimed to investigate the metaphorical conceptions of high school students in Turkey about "learning" and "instruction". For the selection of the participants, stratified sampling, one of the purposive sampling methods, was adopted. The participating students completed the prompts -which were also the data collection instruments- "learning is like... because..." and "instruction is like... because..." to indicate their conceptualizations about learning and instruction. The data were analyzed using content analysis technique. In order to ensure the validity of the study, the data analysis process was described in detail, the findings were presented without any comment on, and an expert's opinion was received to confirm whether metaphors under conceptual categories were represented in conceptual category. To ensure the reliability of the findings, a colleague was asked to match sample metaphorical images with the conceptual categories. The results of the study showed that high school students developed a total of 71 valid metaphors clustered under totally nine (five for learning theme and four for instruction theme) main conceptual categories.
\end{abstract}

Keywords: Metaphors; Learning and instruction; High school students

Article History: Submitted 6 August 2020; Revised 18 October 2020; Published online 25 October 2020

\section{Introduction}

Over the past two decades, researchers have been increasingly interested in metaphor research in order to better understand the conceptualizations such as education, school, curriculum, learning, instruction, and teacher created by teachers and students (Mahlios, Massengill-Shaw, \& Barry, 2010). Although there seems to be a growing body of literature in order to understand such concepts as education, school, curriculum, learning, instruction, student, and teacher (e.g., Anglin \& Dugan, 1982; Aykaç \& Çelik, 2014; Eren \& Tekinarslan, 2013; Gültekin, 2013; Martinez, Sauleda, \& Huber, 2001; Saban, 2003, 2006, 2013; Saban, Koçbeker, \& Saban, 2006, 2007; Shaw, Barry, \& Mahlios, 2008), the related research is seen to be conducted more on in-service or pre-service teachers on how they conceptualize such metaphorical images.

More recently researchers are trying hard to understand schooling processes by analyzing metaphorical images of teachers as well as students (e.g., Güner, 2012; Memnun, 2015; Sevindik, Memnun, \& Çenberci, 2016; Turhan-Türkkan \& Yeşilpınar-Uyar, 2016), so that the use of metaphors in students' talking about learning and instruction may allow to understand different

\footnotetext{
Address of Corresponding Author

Gokhan Bas, PhD, Faculty of Education, Nigde Omer Halisdemir University, 51240, Nigde, Turkey.

$\triangle$ gokhanbas51@gmail.com
}

How to cite: Bas, G. \& Kivılcım, Z. S. (2020). High school students' conceptions about learning and instruction: A metaphor analysis. Journal of Pedagogical Research, 4(3), 272-290. 
articulations in schooling (Mouraz, Pereira, \& Monteiro, 2013). While the research in regard of students' metaphorical images in order to understand schooling processes is lacking, their perceptions and viewpoints about learning and instruction are seen to be very important so as to sustain an effective instruction by teachers (Saban, Koçbeker, \& Saban, 2007). There are some ways of examining students' affective characteristics and viewpoints to identify the conceptual devices about learning and instruction. Students' affective characteristics and viewpoints to identify the conceptual devices about learning and instruction may be examined via qualitative and quantitative ways such as surveying, interviewing, etc. (Creswell, 2012; Fraenkel \& Wallen, 2009). Also, one way of examining students' affective characteristics and viewpoints to identify the conceptual devices they use to make sense of learning and instruction may be through metaphors. In this regard, it is considered that metaphors have an important place in finding out students' affective characteristics and viewpoints. Thus, metaphors are considered crucial tools to conceptualize the nature of learning and instruction through the eyes of students, and to make connections between personal beliefs and educational theory.

\subsection{Literature Review}

The research regarding metaphors about learning, instruction, and schooling is quite vast in the literature. For example, Inbar (1996) collected data from different schools. In this study, he requested the participants to think about the following four images: "The student is like...", "the teacher is like...", "the principal is like...", and "the school is like....". With his study, he categorized over 7000 metaphorical images of what the teacher, the learner, the principal, and the school is. Generally, most of the educators tended to perceive themselves more in a caring position while the majority of the students tended to focus more on the evaluative and controlling aspects of teaching in the study.

Oxford, Tomlinson, Barcelos, Harrington, Lavine, and Saleh (1998) carried out a study that aimed to conceptualize the teaching process and the role of language teachers. They collected data from students, teachers, and former students in order to explore the various concepts of a language teacher. They organized the elicited metaphors for teachers around four different philosophies of education that have shaped educational thought through the centuries. They are: social order, cultural transmission, learner centered growth, and social reform.

Cortazzi and Jin (1999) explored teachers' and prospective teachers' metaphors about teaching, learning, and language. They found that teachers' account of significant learning event is deeply and widely pervaded by metaphors. They also found some conceptual metaphors such as "learning is a click", "learning is light", "learning is movement", "learning is a jigsaw", etc. in their study.

Martinez, Sauleda, and Huber (2001) examined the metaphorical conceptions of teaching and learning coming from experienced elementary school teachers and fourth-year prospective teachers in their study. The findings of the study were analyzed according to three theoretical perspectives: the behaviorist perspective, the constructivist perspective, and the socio-cultural perspective. The results indicated that the majority of both experienced teachers and prospective teachers shared traditional metaphors depicting teaching and learning as transmission of knowledge.

Bozlk (2002) explored first-year college students' metaphors for themselves as learners at four points during an academic year. The metaphors were then analyzed and categorized into four main groups. The metaphorical conceptions identified at the end of the study were animal metaphors, (e.g., snail, fish), object metaphors (e.g., sponge, crayon), human metaphors (e.g., toddler, entrepreneur), and action metaphors (e.g., drying a counter).

In a study carried out by Saban (2004), exit level prospective teachers' metaphors regarding the concepts of elementary school teacher, cooperating teacher, and self-as a future teacher. He found that the prospective teachers' metaphors can be classified as teacher-centered metaphors (e.g, customer, shopkeeper, and racing horse) and student-centered metaphors (e.g., flower, explorer, 
and player) within the framework of each theme (e.g., elementary school teacher, cooperating teacher, and self-as a future teacher).

Saban (2006) in his study reviewed the pertinent research literature on metaphors in teaching and teacher education. He explored the metaphors as evidence of prospective and practicing teachers' reasoning about teaching, learning, and schooling. The review was organized around major functions of metaphors in education. By this way, the author intended to contribute to the field of teaching and teacher education stemming largely from metaphor analysis. The study discussed to distinct functions of metaphor in education and provided illustrative studies for each function.

Saban, Koçbeker, and Saban (2006) in a different study, examined and classified the metaphors that prospective teachers formulated to describe the concept of teacher. They collected data from prospective teachers in an education faculty in Turkey. In their study, they requested the participants to complete the prompt "A teacher is like... because..." by focusing only one metaphor to indicate their conceptualizations of teaching and learning. According to the findings of the study, 111 valid personal metaphors and 10 main conceptual categories, based on the participants' metaphorical images, were identified.

Saban, Koçbeker, and Saban (2007) examined prospective teachers' conceptions of teaching and learning revealed through metaphor analysis in their study. They investigated the metaphors that prospective teachers in Turkey formulated to describe the concept of "teacher". Participants completed the prompt "A teacher is like... because..." by focusing on only one metaphor to indicate their conceptualization of teaching and learning. They found out six dominant conceptual themes for teacher such as knowledge provider, craftsperson, facilitator/scaffolder, nurturer/cultivator, counselor, and cooperative/democratic leader in their research.

Saban (2010) explored the metaphorical images that prospective teachers in Turkey formulated to describe the concept of learner. Participants completed the prompt "A student is like... because..." to indicate their conceptualizations of learner. Data was analyzed both qualitatively and quantitatively. Altogether 156 valid metaphorical images were identified and 11 main conceptual themes were developed. Also, significant associations were detected between participants' gender, class level, and program type and the 11 conceptual themes.

Kalra and Baveja (2012) carried out a large study that comprised a sample of prospective and inservice teachers in India with the objective of analyzing their beliefs or personal theories about knowledge, learning, and learners. The participants were required to complete the following statements with the images that came to their minds while completing the following statements: "Learners are like....", "learning is like...", and "knowledge is like..." in the research. The findings of the study indicated that the participants unconsciously constructed and used their own metaphors that became the basis of their conceptualizations about the three concepts - knowledge, learning, and learners.

More recently, in a different study made by Saban (2013) Turkish primary prospective teachers' experienced and ideal images of learning through metaphors were examined. The participants of this phenomenological study included sophomores. The participants were asked to complete "For me, learning was like... because..." and "to me, learning is/should be like... because...". With his study, a total of 47 metaphorical images were produced by the participants. Out of 45 metaphorical images, 18 images represented their experienced learning while 27 of them represented their ideal learning.

Eren and Tekinarslan (2013) examined the prospective teachers' metaphors regarding the concepts of teacher, teaching, learning, instructional material, and evaluation in their study. The results revealed that the metaphors prospective teachers produced regarding the concepts of teacher, teaching, learning, instructional material, and evaluation constituted meaningful and discernible categories each of which has both cognitive and affective aspects, with the exception of the categories regarding learning concept. Results of the study led to these conclusions. First prospective teachers' metaphors regarding the teacher, teaching, learning, instructional material, 
and evaluation constituted meaningful and discernible categories. Second these categories, with the exception of the categories regarding learning, contained prominent cognitive and affective aspects.

It can be concluded that the research regarding metaphors about learning, instruction, and schooling is not rare. As the literature is given shortly above, it can be well understood that nearly all of the research regarding the metaphorical conceptions about learning, instruction and schooling has focused on prospective or in-service teachers. It is believed that being a studentteacher or a teacher (prospective or/and in-service) focusing on learning and instruction seems to be a factor that differentiates such conceptions.

\subsection{The Aim}

The perceptions of students in terms of learning and instruction may contribute to the construction of an effective learning and instruction process by teachers, and may also affect teachers' decisionmaking processes and lead their behaviors in the classroom. In this study, high school students' metaphorical conceptions about learning and instruction are examined, unlike the vast amount of research investigating the metaphorical conceptions used by pre-service and in-service teachers. It is believed that understanding metaphorical conceptions of students regarding learning and instruction might help teachers to design the learning environment better. Considering students' conceptions about learning and instruction can help teachers understand students' way of learning, thus it may contribute to crate student-centered learning environments. Understanding students' conceptions about learning and instruction may also help teachers gain insights into their teaching style, which shows the quality of teaching-learning process. So, it is posited that metaphorical conceptions of students about learning and instruction may affect classroom practices. Therefore, the present study aims at examining: the metaphors that high school students use to describe the concept of "learning" and the metaphors that high school students use to describe the concept of "instruction". The problem statement of the study was defined as "What are the conceptions of students about learning and instruction?" In order to find an answer to the problem statement, the following research questions were addressed:

1. Which metaphors do students produce to conceptualize the concept of learning?

2. Which metaphors do students produce to conceptualize the concept of instruction?

\section{Method}

\subsection{Research Design}

In this study, we used the phenomenological research, one of the qualitative research designs to examine high school students' metaphorical conceptions about learning and instruction. According to Patton (1990), a phenomenological study is one of that focus on description what people experience and how it is that they experience what they experience (p. 71). As Creswell (1998) states, "a phenomenological study describes the meaning of the lived experience for several individuals about a concept or phenomenon" (p. 51). It is thought that phenomenological design is appropriate in revealing the past lives and experiences of students. Because, this pattern focuses on the shared experiences of a group of people.

\subsection{Procedures}

The participants of the study were 1.082 volunteering students enrolled in three different public high schools in Nigde province, a rather small province with a population of 343.658 (Turkish Statistical Institution [TurkStat], 2013) in the central Anatolia region of Turkey. For the selection of the participants, stratified sampling, one of the purposive sampling methods, was adopted (Creswell, 2012). This method is used to identify the characteristics of sub-groups and make comparisons between these groups (Fraenkel \& Wallen, 2009). There are three high school types in the Turkish Education System, including Science High School, Anatolian High School, and Vocational High School. Therefore, these types of high schools constitute sub-groups in the high 
school system. Therefore, we attempted to include all high school types in the study, so as to gain insights into high school students' conceptions about learning and instruction.

Of the participants, $42.70 \%(n=462)$ were boys and $57.30 \%(n=620)$ were girls in the study. Anatolian high school students $(n=490,45.28 \%)$ constituted the largest group, followed by science high school students $(n=374,34.56 \%)$ and vocational high school students $(n=218,20.35 \%)$. With regard to class-size, $334(30.87 \%)$ students were enrolled in the $9^{\text {th }}$ grade, $286(26.43 \%)$ students were enrolled in the $10^{\text {th }}$ grade, $258(23.85 \%)$ students were enrolled in the $11^{\text {th }}$ grade, and 204 $(18.85 \%)$ students were enrolled in the $12^{\text {th }}$ grade in the study. Finally, the participants' age ranged from 14 to 18 years $(M=16, S D=.82)$ in the research.

\subsection{Data Collection}

With the aims of identifying high school students' metaphorical conceptions about learning and instruction, we asked each participant to complete the prompts "Learning is like... because..." and "Instruction is like... because..." by focusing only one metaphor for each prompt. We also asked the participants to focus on the metaphors for each prompt they have written and clarify the reason(s) for choosing their own metaphors. We delivered a blank piece of paper on which the prompts were written. We gave the participants one class-hour (40 min. duration) to write about a metaphorical image that represented their thoughts about learning and instruction. We did it so because we wanted to know participants' immediate reactions towards learning and instruction concepts. We asked the participants to make learning and instruction resemble to something (a metaphorical image) by using the word like, and give a sensible reason to the metaphorical image they created by using the word because in the research. In this way, we wanted the participants to resemble learning and instruction to something by giving a sensible reason for them.

On the other hand, three colleagues who work in the mentioned high schools helped us to administer the papers on which two distinct prompts were written to the participants. We visited the high schools two times each week to understand the conceptions of students about learning and instruction better. During data collection, we did not face with any problems that threaten the validity and reliability of the study.

\subsection{Data Analysis}

We analyzed the data of the study following the steps of a metaphor analysis (see Moser, 2000). We adopted the following steps, proposed by Saban, Koçbeker, and Saban $(2006,2007)$ in the analysis of the metaphors of the current research. The steps suggested by Saban, Koçbeker, and Saban $(2006,2007)$ in the analysis of metaphors in a research can be summarized as: naming/labeling stage, sorting (clarification and elimination), sample metaphor compilation and categorization, establishing the validity and reliability, and analyzing the data quantitatively.

In the first step of the analysis, we created a temporary list of all metaphors produced by students according to the alphabetical order by using MS Word 2007 software in the study. In this stage, we simply coded the name of the metaphor and the metaphor that did not have a logical basis or a rationale which we marked as "discarded" on the prompt, was eliminated from the data. In the second step, we went through the raw data to analyze in order to find similarities or common features with the other metaphors. So, we broke each metaphorical image down into analyzable parts, looking for common elements or features amongst the various metaphors. After the naming/labeling and sorting steps, a total of 35 papers due to the methodological reasons were eliminated from the data. After the students' papers containing poorly (weak) structured metaphors being extracted, totally 982 available papers were subjected to sample metaphor compilation and categorization step. In this step, we reviewed the raw data again and reorganized the remaining metaphors in order to choose a sample expression that represented each identified metaphor. Our purpose in this step was to generalize from exemplar metaphors we compiled to the conceptual themes. First, we picked the phrase expressions that we considered represented the specific metaphors best. We analyzed metaphors produced by the students in terms of common characteristics they had relations with learning and instruction concepts. Then, we coded each 
metaphor so that it could fit into one logical conceptual theme in the study. As a result of our inductive analysis, we identified five major themes for learning concept and four major themes for instruction concept.

In order to ensure the validity of the research, the data analysis process was described in detail, and the findings were presented without making any comment on them (Creswell, 1998; Merriam, 1998). Also, to ensure the validity of the findings of the study, we took an expert's opinion to confirm whether metaphors under conceptual categories represented in question to any conceptual category or not. We asked the expert to appoint some of the metaphors into some of the defined conceptual themes in order to clarify metaphors fit into those defined conceptual categories. Then, to ensure the reliability of the findings, we asked a colleague to match sample metaphorical images with the conceptual categories. In order to estimate the reliability rate, we used the formula, Reliability $=[$ Agreement $/($ Agreement + Disagreement $)] x 100$ produced by Miles and Huberman (1994). Later, we compared our colleague's matching with our own metaphorical matching in terms of the conceptual categories. In the comparison, we calculated agreement and disagreement scores and found the reliability as $98 \%$, Reliability $=[70 /(70+1)] \times 100=.98$. In qualitative studies, the desirable level of quality is provided in any cases where the compliance between expert(s) and researcher(s) is over 90\% (Miles \& Huberman, 1994). In the last step of data analysis process, we entered the data into SPSS for Windows 17.0 package program in order to calculate frequencies $(f)$ and percentages $(\%)$ of the metaphors in each category.

\section{Findings}

In this section of the study, we analyzed the findings that high school students produced regarding the metaphors for learning and instruction. We first introduced the general results and the conceptual categories regarding learning and instruction concepts.

\subsection{General Findings}

High school students participated in the study produced a total of 46 well-structured metaphors for "learning" concept and a total of 25 well-structured metaphors for "instruction" concept. In the research, Science High School (SHS) students produced 71 metaphors, Anatolian High School (AHS) students generated 70 metaphors, and Vocational High School (VHS) students developed 58 metaphors both for learning and instruction concepts. The top five dominant metaphors included the following for learning concept: (1) book $(n=63,5.82 \%)$, (2) tree $(n=61,5.63 \%)$, (3) reading $(n=52,4.80 \%)$, (4) water $(n=48,4.43 \%)$, and (5) teacher $(n=47,4.34 \%)$ and for instruction concept: (1) sun $(n=78,7.20 \%)$, (2) carpentering $(n=71,6.56 \%)$, (3) teacher $(n=61,5.63 \%)$, (4) planting tree $(n=59,5.45 \%)$, and (5) painting $(n=57,5.26 \%)$ in the study.

Of the total 71 metaphors produced in the study, 28 were about activities (e.g., watering, composing, acting), 2 were about human beings (e.g., teacher), and 41 were about inanimate things and/or objects (e.g., computer, book, cooking). Besides, out of 71 total metaphors, only one of them was formulated by SHS students (e.g., vegetable), and the rest of them were produced mutually by SHS, AHS, and VHS students. On the contrary, a total 58 metaphors were common amongst all the participating students from three different high schools in the research. Also, a total of 70 metaphors were produced by those students from at least two high schools. Furthermore, we observed that female students produced more metaphors than their male peers in the study. Out of 71 metaphors produced in the study, 40 metaphors were generated by only female students, whereas 31 metaphors were formulated only by male students. Finally, we discovered five main conceptual categories for learning and four main conceptual categories for instruction. The main conceptual categories for learning were: learning as a basic human need, learning as a cultivating activity, learning as a source of knowledge, learning as a challenging process, and learning as a joyful activity and for instruction were: Instruction as an art, instruction 
as a cultivating facility, instruction as a constructive process, and instruction as knowledge provider in the study.

\subsection{Main Conceptual Categories for Learning}

\subsubsection{Learning as a basic human need}

The first conceptual category for learning is "learning as a basic human need". There are 161 students $(14.8 \%)$ and 11 well-structured metaphors $(23.9 \%)$ for learning as a basic human need conceptual category and the following five metaphors are found to be dominant in the study: (1) water $(4.43 \%)$, (2) meal (3.78\%), (3) food (2.49\%), (4) air $(2.03 \%)$, and (5) breath $(0.83 \%)$. Also, these 5 metaphors (water, meal, food, air, and breath) are found to be common amongst students from the three different high schools in the research (see Table 1). In this conceptual category, SHS students provided 11 metaphorical images, AHS students articulated 10 metaphorical images and VHS students produced 5 metaphorical images.

Table 1.

Learning as a basic human need

\begin{tabular}{|c|c|c|c|c|c|c|c|c|}
\hline \multirow[t]{2}{*}{ Metaphor Name } & \multicolumn{2}{|c|}{$\begin{array}{c}\text { SHS } \\
(n=374)\end{array}$} & \multicolumn{2}{|c|}{$\begin{array}{c}\text { AHS } \\
(n=490)\end{array}$} & \multicolumn{2}{|c|}{$\begin{array}{c}\text { VHS } \\
(n=218)\end{array}$} & \multicolumn{2}{|c|}{$\begin{array}{c}\text { Total } \\
(n=1.082)\end{array}$} \\
\hline & $f$ & $\%$ & $f$ & $\%$ & $f$ & $\%$ & $f$ & $\%$ \\
\hline 1.Water & 17 & 4.54 & 21 & 4.28 & 10 & 4.58 & 48 & 4.43 \\
\hline 2.Meal & 13 & 3.47 & 20 & 4.08 & 8 & 3.66 & 41 & 3.78 \\
\hline 3.Food & 11 & 2.94 & 10 & 2.04 & 6 & 2.75 & 27 & 2.49 \\
\hline 4.Air & 10 & 2.67 & 8 & 1.63 & 4 & 1.83 & 22 & 2.03 \\
\hline 5.Breath & 5 & 1.33 & 3 & 0.61 & 1 & 0.45 & 9 & 0.83 \\
\hline 6.Hunger & 3 & 0.80 & 1 & 0.20 & - & - & 4 & 0.36 \\
\hline 7.Sweet & 2 & 0.53 & 1 & 0.20 & - & - & 3 & 0.27 \\
\hline 8.Cookie & 1 & 0.26 & 1 & 0.20 & - & - & 2 & 0.18 \\
\hline 9.Tea & 1 & 0.26 & 1 & 0.20 & - & - & 2 & 0.18 \\
\hline 10.Coffee & 1 & 0.26 & 1 & 0.20 & - & - & 2 & 0.18 \\
\hline 11.Vegatable & 1 & 0.26 & - & - & - & - & 1 & 0.09 \\
\hline Total & & & & & & & & \\
\hline Student & 64 & 17.1 & 66 & 13.4 & 29 & 13.3 & 161 & 14.8 \\
\hline Metaphor & 11 & 23.9 & 10 & 21.7 & 5 & 10.8 & 11 & 23.9 \\
\hline
\end{tabular}

Note. SHS = Science High School, AHS = Anatolian High School, VHS = Vocational High School

In this conceptual category, learning is seen as a basic human need (e.g., water, food, meal, air, breath) which the students think they cannot live without them. Therefore, the students mostly see the learning concept as the source of living which they believe that they cannot live without it. In this category, learning is simply seen as a way of living and being in life. From this standpoint of this conceptual theme, learning is viewed as equal to living, which the students have to learn in order to live. Besides, the students see learning as the same of living which they believe they cannot live without learning in life. We can see some extended comments in this conceptual category as follows:

Leaning is like water, because it is the source of living ( $M, S H S)$.

Learning is like food, because we can't live without it (F, AHS).

Learning is like air, because we die without breathing it (M, VHS).

\subsubsection{Learning as a cultivating activity}

Altogether, there are 242 students (22.3\%) and 9 metaphors $(19.5 \%)$ under the second conceptual category for learning. The top five dominant metaphors for learning as a cultivating activity category are as follows: (1) tree (5.63\%), (2) seed (3.88\%), (3) field (3.51\%), (4) crop (2.49\%), and (5) 
watering $(2.12 \%)$. Also, we see that all nine metaphors are common amongst all the students from the three different high schools in the study (see Table 2). In this conceptual category, all students from the three different high schools (SHS, AHS and VHS) produced 9 metaphorical images each.

Table 2.

Learning as a cultivating activity

\begin{tabular}{lcccccccc}
\hline Metaphor Name & \multicolumn{2}{c}{$\begin{array}{c}\text { SHS } \\
(\mathrm{n}=374)\end{array}$} & \multicolumn{2}{c}{$\begin{array}{c}\text { AHS } \\
(\mathrm{n}=490)\end{array}$} & \multicolumn{2}{c}{$\begin{array}{c}\text { VHS } \\
(\mathrm{n}=218)\end{array}$} & \multicolumn{2}{c}{$\begin{array}{c}\text { Total } \\
(\mathrm{n}=1.082)\end{array}$} \\
\cline { 2 - 10 } & $\mathrm{f}$ & $\%$ & $\mathrm{f}$ & $\%$ & $\mathrm{f}$ & $\%$ & $\mathrm{f}$ & $\%$ \\
\hline 1.Tree & 24 & 6.41 & 21 & 4.28 & 16 & 7.33 & 61 & 5.63 \\
2.Seed & 13 & 3.47 & 18 & 3.67 & 11 & 5.04 & 42 & 3.88 \\
3.Field & 11 & 2.94 & 19 & 3.87 & 8 & 3.66 & 38 & 3.51 \\
4. Crop & 10 & 2.67 & 14 & 2.85 & 3 & 1.37 & 27 & 2.49 \\
5.Watering & 11 & 2.94 & 10 & 2.04 & 2 & 0.91 & 23 & 2.12 \\
6.Planting & 8 & 2.13 & 8 & 1.63 & 5 & 2.63 & 21 & 1.94 \\
7.Farming & 7 & 1.87 & 5 & 1.02 & 3 & 1.37 & 15 & 1.38 \\
8.Harvesting & 2 & 0.53 & 3 & 0.61 & 3 & 1.37 & 8 & 0.73 \\
9.Ploughing & 2 & 0.53 & 1 & 0.20 & 4 & 1.83 & 7 & 0.64 \\
Total & & & & & & & & \\
\hline \multicolumn{1}{c}{ Student } & 88 & 23.5 & 99 & 20.2 & 55 & 25.2 & 242 & 22.3 \\
$\quad$ Metaphor & 9 & 19.5 & 9 & 19.5 & 9 & 19.5 & 9 & 19.5 \\
\hline
\end{tabular}

Note. SHS = Science High School, AHS = Anatolian High School, VHS = Vocational High School

In this conceptual category, learning is viewed as a cultivating activity (e.g., seed, tree, field) which the students see learning as a cultivating activity such as planting trees, seeding, ploughing field, and watering plantation. In this category, learning is simply perceived as rather long processes which people plant and then wait to harvest. Within this conceptual theme, the students view learning as an activity such as cultivating which they plant seeds, water, plough the field, and then collect the crops. From this standpoint of this conceptual category, learning is seen as the same of cultivating since the students need to learn in order to collect crops and then use it in their school and/or after school lives. We can see some extended comments in this conceptual category as follows:

Learning is like a tree, because you plant it for your future ( $F, A H S)$.

Learning is like a seed, because you get remunerate ( $M, V H S)$.

Learning is like water, because it helps you to grow up your crops (M, AHS).

\subsubsection{Learning as a source of knowledge}

The third conceptual category for learning is "learning as a source of knowledge". There are 300 students $(27.7 \%)$ and 10 metaphors $(21.7 \%)$ for learning as a source of knowledge and the following five metaphors are found to be dominant in the study: (1) book (5.82\%), (2) reading $(4.80 \%)$, (3) teacher $(4.34 \%),(4)$ school $(3.78 \%)$, and (5) course $(2.95 \%)$. Also, 8 metaphors (book, reading, teacher, school, course, library, life, and computer) are seen to be common amongst all students from the three different high schools in the research (see Table 3). In this conceptual category, SHS and AHS students produced 10 metaphorical images each, whereas VHS students generated 8 metaphorical images. 
Table 3.

Learning as a source of knowledge

\begin{tabular}{|c|c|c|c|c|c|c|c|c|}
\hline \multirow[t]{2}{*}{ Metaphor Name } & \multicolumn{2}{|c|}{$\begin{array}{c}\text { SHS } \\
(\mathrm{n}=374)\end{array}$} & \multicolumn{2}{|c|}{$\begin{array}{c}\text { AHS } \\
(\mathrm{n}=490)\end{array}$} & \multicolumn{2}{|c|}{$\begin{array}{c}\text { VHS } \\
(\mathrm{n}=218)\end{array}$} & \multicolumn{2}{|c|}{$\begin{array}{c}\text { Total } \\
(\mathrm{n}=1.082)\end{array}$} \\
\hline & $\mathrm{f}$ & $\%$ & $\mathrm{f}$ & $\%$ & $\mathrm{f}$ & $\%$ & $\mathrm{f}$ & $\%$ \\
\hline 1.Book & 22 & 5.88 & 25 & 5.10 & 16 & 7.33 & 63 & 5.82 \\
\hline 2.Reading & 18 & 4.81 & 21 & 4.28 & 13 & 5.96 & 52 & 4.80 \\
\hline 3.Teacher & 17 & 4.54 & 19 & 3.87 & 11 & 5.04 & 47 & 4.34 \\
\hline 4. School & 14 & 3.74 & 17 & 3.46 & 10 & 4.58 & 41 & 3.78 \\
\hline 5.Course & 11 & 2.94 & 13 & 2.65 & 8 & 3.66 & 32 & 2.95 \\
\hline 6.Library & 7 & 1.87 & 8 & 1.63 & 3 & 1.37 & 18 & 1.66 \\
\hline 7.Life & 6 & 1.60 & 9 & 1.83 & 2 & 0.91 & 17 & 1.57 \\
\hline 8.Computer & 7 & 1.87 & 7 & 1.42 & 1 & 0.45 & 15 & 1.38 \\
\hline 9.Internet & 5 & 1.33 & 3 & 0.61 & - & - & 8 & 0.73 \\
\hline 10.SNS & 3 & 0.80 & 4 & 0.81 & - & - & 7 & 0.64 \\
\hline Total & & & & & & & & \\
\hline Student & 110 & 29.4 & 126 & 25.7 & 64 & 29.3 & 300 & 27.7 \\
\hline Metaphor & 10 & 21.7 & 10 & 21.7 & 8 & 17.3 & 10 & 21.7 \\
\hline
\end{tabular}

Note. SHS = Science High School, AHS = Anatolian High School, VHS = Vocational High School, SNS = Social Network System

In this conceptual category, learning is seen as a source of knowledge (e.g., book, reading, teacher, library) which the students are passive recipients of it. The students generally consider book, teacher, school, course, and library as the sources of knowledge which they believe knowledge is transmitted from these things/objects to them. Also, life is viewed as a source of knowledge which students think that life is a thing from which they can learn. Besides, computer, Internet, and SNS such as Facebook and Twitter are also perceived as the sources of knowledge which the students believe they get/reach all the information via them. From the standpoint of this conceptual category, learning is mostly viewed as the traditional sources of knowledge such as book, school, teacher, and library. Furthermore, as most of the students are active users of computer-based technologies and applications, we consider that they see these technologies and applications as a source of knowledge. We can see some extended comments in this conceptual category as follows for exemplars:

Learning is like a book, because you can learn all the information from them ( $M, S H S)$.

Learning is like a teacher, because they teach you what is good or what is bad (F, AHS).

Learning is like the Internet, because you can find all the information you need in it (M, AHS).

\subsubsection{Learning as a challenging process}

The fourth conceptual category for learning is "learning as a need basic challenging process". There are 180 students $(16.6 \%)$ and 10 well-structured metaphors $(21.7 \%)$ for learning as a challenging process conceptual category and the following five metaphors are found to be dominant in the study: (1) exams (3.60\%), (2) torture (3.14\%), (3) bottomless well $(2.68 \%)$, (4) all unknown $(2.21 \%)$, and (5) black hole (1.47\%). Also, 8 metaphors (exams, torture, bottomless well, all unknown, black hole, infinity, universe, and sun) are found to be common amongst the students from the three different high schools in the research (see Table 4). In this conceptual category, SHS and AHS students provided 10 metaphorical images each, whereas VHS students produced 8 metaphorical images. 
Table 4.

Learning as a challenging process

\begin{tabular}{lllllllll}
\hline Metaphor Name & \multicolumn{2}{c}{$\begin{array}{c}\text { SHS } \\
(\mathrm{n}=374)\end{array}$} & \multicolumn{2}{c}{$\begin{array}{c}\text { AHS } \\
(\mathrm{n}=490)\end{array}$} & \multicolumn{2}{c}{$\begin{array}{c}\text { VHS } \\
(\mathrm{n}=218)\end{array}$} & \multicolumn{2}{c}{$\begin{array}{c}\text { Total } \\
(\mathrm{n}=1.082)\end{array}$} \\
\cline { 2 - 10 } & $\mathrm{f}$ & $\%$ & $\mathrm{f}$ & $\%$ & $\mathrm{f}$ & $\%$ & $\mathrm{f}$ & $\%$ \\
\hline 1.Exams & 12 & 3.20 & 16 & 3.26 & 11 & 5.04 & 39 & 3.60 \\
2.Torture & 11 & 2.94 & 14 & 2.85 & 9 & 4.12 & 34 & 3.14 \\
3. Bottomless well & 10 & 2.67 & 13 & 2.65 & 6 & 2.75 & 29 & 2.68 \\
4.All unknown & 9 & 2.40 & 11 & 2.24 & 4 & 1.83 & 24 & 2.21 \\
5.Black hole & 6 & 1.60 & 8 & 1.63 & 2 & 0.91 & 16 & 1.47 \\
6.Infinity & 5 & 1.33 & 6 & 1.22 & 1 & 0.45 & 12 & 1.10 \\
7.Universe & 4 & 1.06 & 3 & 0.61 & 1 & 0.45 & 8 & 0.73 \\
8.Space & 3 & 0.80 & 4 & 0.81 & - & - & 7 & 0.64 \\
9.Sea & 2 & 0.53 & 4 & 0.81 & - & - & 6 & 0.55 \\
10.Sun & 2 & 0.53 & 2 & 0.40 & 1 & 0.45 & 5 & 0.46 \\
Total & & & & & & & & \\
\hline \multicolumn{1}{l}{ Student } & 64 & 17.1 & 81 & 16.5 & 35 & 16.0 & 180 & 16.6 \\
$\quad$ Metaphor & 10 & 21.7 & 10 & 21.7 & 8 & 17.3 & 10 & 21.7 \\
\hline
\end{tabular}

Note. SHS = Science High School, AHS = Anatolian High School, VHS = Vocational High School

In this conceptual category, learning is seen as a challenging process (e.g., exams, torture, bottomless well, all unknown, black hole) which the students consider learning is a hard thing to do. Therefore, the students mostly see the learning concept as a challenging process which they believe they do it hardly. The students resemble learning to difficult or challenging things such as exams and torture. Also, the students believe that learning is a challenging process and endless things such as bottomless well, black hole, infinity, universe, space and all unknown which they can never reach the end. From this standpoint of this conceptual theme, learning is viewed as equal to challenging things, which the students see as exams, torture and bottomless well. We can see some extended comments in this conceptual category as follows for exemplars:

Learning is like exams, because it is hard to achieve them (F, SHS).

Learning is like torture, because you sometimes never want to do (M, AHS).

Learning is like a bottomless well, because you never reach the end it (M, SHS).

\subsubsection{Learning as a joyful activity}

Altogether, there are 99 students (9.1\%) and 6 metaphors (13\%) under the last conceptual category for learning. There are fewer metaphors produced in this conceptual category compared to the other categories of learning concept, so we present only the top three dominant metaphors for this category. Thus, the top three dominant metaphors for learning as a joyful activity category are as follows: (1) playing games (2.58\%), (2) shopping (2.03\%), and (3) doing sports (1.84\%). Also, we see that 5 metaphors are common amongst all students from the three different high schools in the study (see Table 5). In this conceptual category, SHS and AHS students produced 6 metaphorical images each, whereas VHS students generated 5 metaphorical images.

In the last conceptual category, learning is viewed as a joyful activity (e.g., playing games, shopping, doing sports) which the students simply see learning as an amusing activity such as playing games, doing shopping, doing sports, singing, watching television, etc. From this standpoint of this conceptual category, learning is seen as the same of amusement since the students have fun while learning something such as watching television, shopping at a supermarket, sitting at a café, and doing their favorite sports. 
Table 5 .

Learning as a joyful activity

\begin{tabular}{|c|c|c|c|c|c|c|c|c|}
\hline \multirow[t]{2}{*}{ Metaphor Name } & \multicolumn{2}{|c|}{$\begin{array}{c}\text { SHS } \\
(\mathrm{n}=374)\end{array}$} & \multicolumn{2}{|c|}{$\begin{array}{c}\text { AHS } \\
(\mathrm{n}=490)\end{array}$} & \multicolumn{2}{|c|}{$\begin{array}{c}\text { VHS } \\
(\mathrm{n}=218)\end{array}$} & \multicolumn{2}{|c|}{$\begin{array}{l}\text { Total } \\
(\mathrm{n}=1.082)\end{array}$} \\
\hline & $\mathrm{f}$ & $\%$ & $\mathrm{f}$ & $\%$ & $\mathrm{f}$ & $\%$ & $\mathrm{f}$ & $\%$ \\
\hline 1.Playing games & 11 & 2.94 & 12 & 2.44 & 5 & 2.29 & 28 & 2.58 \\
\hline 2.Shopping & 9 & 2.40 & 11 & 2.24 & 2 & 0.91 & 22 & 2.03 \\
\hline 3.Doing sports & 7 & 1.87 & 11 & 2.24 & 2 & 0.91 & 20 & 1.84 \\
\hline 4. Singing & 5 & 1.33 & 7 & 1.42 & 1 & 0.45 & 13 & 1.20 \\
\hline 5.Watching TV & 3 & 0.80 & 5 & 1.02 & 3 & 1.37 & 11 & 1.01 \\
\hline $\begin{array}{l}\text { 6.Sitting at a café } \\
\text { Total }\end{array}$ & 2 & 0.53 & 3 & 0.61 & - & - & 5 & 0.46 \\
\hline Student & 49 & 13.1 & 37 & 7.5 & 13 & 5.9 & 99 & 9.1 \\
\hline Metaphor & 6 & 13.0 & 6 & 13.0 & 5 & 10.8 & 6 & 13.0 \\
\hline
\end{tabular}

Note. SHS = Science High School, AHS = Anatolian High School, VHS = Vocational High School

We can see some extended comments in this conceptual category as follows for exemplars:

Learning is like playing a game, because you have fun while spending you time on it (M, AHS).

Learning is like shopping, because you can get all you need and have fun (F, AHS).

Learning is like doing sports, because you renew yourself ( $F, V H S)$.

\subsection{Main Conceptual Categories for Instruction}

\subsubsection{Instruction as an art}

The first conceptual category for instruction is "instruction as an art". There are 263 students $(24.3 \%)$ and 7 well-structured metaphors (28\%) for instruction as an art conceptual category and the following five metaphors are found to be dominant in the study: (1) carpentering (6.56\%), (2) painting (5.26\%), (3) embroidering (4.34\%), (4) conducting (3.51\%), and (5) sculpturing (2.68\%). Also, all seven metaphors (carpentering, painting, embroider, conducting, sculpturing, composing, and acting) are found to be common amongst students from the three different high schools in the research (see Table 6). In this conceptual category, all SHS, AHS, and VHS students provided 7 metaphorical images each.

Table 6.

Instruction as an art

\begin{tabular}{lllllllll}
\hline \multirow{2}{*}{ Metaphor Name } & \multicolumn{2}{c}{$\begin{array}{c}\text { SHS } \\
(\mathrm{n}=374)\end{array}$} & \multicolumn{2}{c}{$\begin{array}{c}\text { AHS } \\
(\mathrm{n}=490)\end{array}$} & \multicolumn{2}{c}{$\begin{array}{c}\text { VHS } \\
(\mathrm{n}=218)\end{array}$} & \multicolumn{2}{c}{$\begin{array}{c}\text { Total } \\
(\mathrm{n}=1.082)\end{array}$} \\
\cline { 2 - 10 } & $\mathrm{f}$ & $\%$ & $\mathrm{f}$ & $\%$ & $\mathrm{f}$ & $\%$ & $\mathrm{f}$ & $\%$ \\
\hline 1.Carpentering & 25 & 6.68 & 27 & 5.51 & 19 & 6.76 & 71 & 6.56 \\
2.Painting & 22 & 5.88 & 23 & 4.69 & 12 & 4.27 & 57 & 5.26 \\
3.Embroidering & 17 & 4.54 & 20 & 4.08 & 10 & 3.55 & 47 & 4.34 \\
4.Conducting & 14 & 3.74 & 16 & 3.26 & 8 & 2.84 & 38 & 3.51 \\
5.Sculpturing & 11 & 2.94 & 13 & 2.65 & 5 & 1.77 & 29 & 2.68 \\
6.Composing & 8 & 2.13 & 4 & 0.81 & 2 & 0.71 & 14 & 1.29 \\
7.Acting & 2 & 0.53 & 4 & 0.81 & 1 & 0.35 & 7 & 0.64 \\
Total & & & & & & & & \\
\hline$\quad$ Student & 99 & 26.4 & 107 & 21.8 & 57 & 20.2 & 263 & 24.3 \\
$\quad$ Metaphor & 7 & 28 & 7 & 28 & 7 & 28 & 7 & 28 \\
\hline
\end{tabular}

Note. SHS = Science High School, AHS = Anatolian High School, VHS = Vocational High School

In this conceptual category, instruction is seen as an art (e.g., carpentering, painting, sculpturing) which the students think instruction is an activity such as an art branch. Therefore, the students mostly see the instruction concept as an art which they believe their teachers make 
artistic activities such as painting, sculpturing, acting, etc. in the classroom. From this standpoint of this conceptual theme, we can conclude that the students participated in the study see the instruction concept as an art. Besides, the students see themselves as objects to be painted, constructed, composed, and see their teachers as subjects that they make artistic operations on them. We can see some extended comments in this conceptual category as follows:

Instruction is like carpentering, because teachers shape the students as carpenters ( $M, A H S)$. Instruction is like painting, because teachers do paintings by instructing students (F, SHS). Instruction is like embroidering, because teachers embroider students slowly by instructing them (M, VHS).

\subsubsection{Instruction as a cultivating facility}

Altogether, there are 227 students $(20.9 \%)$ and 7 metaphors $(28 \%)$ under the second conceptual category for instruction. The top five dominant metaphors for instruction as a cultivating facility category are as follows: (1) planting tree $(5.45 \%)$, (2) seeding $(4.34 \%)$, (3) ploughing (3.51\%), (4) gardening $(2.95 \%)$, and (5) farming $(2.21 \%)$. Also, we see that all 7 metaphors are common amongst all students from the three different high schools in the study (see Table 7). In this conceptual category, SHS, AHS, and VHS students produced 7 metaphorical images each.

Table 7.

Instruction as a cultivating facility

\begin{tabular}{lllllllll}
\hline Metaphor Name & \multicolumn{2}{c}{$\begin{array}{c}\text { SHS } \\
(\mathrm{n}=374)\end{array}$} & \multicolumn{2}{c}{$\begin{array}{c}\text { AHS } \\
(\mathrm{n}=490)\end{array}$} & \multicolumn{2}{c}{$\begin{array}{c}\text { VHS } \\
(\mathrm{n}=218)\end{array}$} & \multicolumn{2}{c}{$\begin{array}{c}\text { Total } \\
(\mathrm{n}=1.082)\end{array}$} \\
\cline { 2 - 10 } & $\mathrm{f}$ & $\%$ & $\mathrm{f}$ & $\%$ & $\mathrm{f}$ & $\%$ & $\mathrm{f}$ & $\%$ \\
\hline 1.Planting tree & 21 & 5.61 & 24 & 4.89 & 15 & 6.88 & 59 & 5.45 \\
2.Seeding & 17 & 4.54 & 19 & 3.87 & 11 & 5.04 & 47 & 4.34 \\
3.Ploughing & 15 & 4.01 & 13 & 2.65 & 10 & 4.58 & 38 & 3.51 \\
4.Gardening & 12 & 3.20 & 14 & 2.85 & 6 & 2.75 & 32 & 2.95 \\
5. Farming & 9 & 2.40 & 12 & 2.44 & 3 & 3.76 & 24 & 2.21 \\
6.Growing up & 6 & 1.60 & 8 & 1.63 & 2 & 0.91 & 16 & 1.47 \\
flowers & & & & & & & & \\
7.Harvesting & 4 & 1.06 & 5 & 1.02 & 2 & 0.91 & 11 & 1.01 \\
Total & & & & & & & & \\
\hline$\quad \begin{array}{l}\text { Student } \\
\quad \text { Metaphor }\end{array}$ & 74 & 22.4 & 95 & 19.3 & 49 & 22.4 & 227 & 20.9 \\
\hline
\end{tabular}

Note. SHS = Science High School, AHS = Anatolian High School, VHS = Vocational High School

In this conceptual category, instruction is viewed as a cultivating facility (e.g., seeding, planting tree, gardening, ploughing). In this category, instruction is simply perceived as a farming activity which teachers plant trees, seed the field, plough, harvest, etc. Within this conceptual theme, the students view instruction as a cultivating activity which they think teachers plant things such as trees, flowers and seeds, plough the field and then harvest by instruction. The classroom is perceived as a field and garden where trees, flowers and other plantation grow with the cultivation of teachers as gardeners. From this standpoint of this conceptual category, the students participated in the study see themselves as things such as tress, seeds, flowers, and see their teachers as farmers who make cultivating activities. We can see some extended comments in this conceptual category as follows:

Instruction is like a planting tree, because teachers see their crop after long years ( $F, S H S)$.

Instruction is like ploughing, because teachers plant students in the field, wait for months, and then harvest them (M,VHS).

Instruction is like growing up flowers, because teachers gently instruct students to be nice flowers one day (F, AHS). 


\subsubsection{Instruction as a constructive process}

The third conceptual category for instruction is "instruction as a constructive process". There are 124 students $(11.4 \%)$ and 4 metaphors (16\%) for instruction as a constructive process. There are fewer metaphors produced in this conceptual category for instruction concept, so we present only the top three dominant metaphors for this category. Thus, the following three metaphors are found to be dominant in the study: (1) kneading dough (4.43\%), (2) cooking (3.32\%), and (3) constructing $(2.21 \%)$. Also, 3 metaphors (kneading dough, cooking, and constructing) are seen to be common amongst all students from the three different high schools in the research (see Table 8). In this conceptual category, SHS and AHS students produced 4 metaphorical images each, whereas VHS students generated 3 metaphorical images.

Table 8.

Instruction as a constructive process

\begin{tabular}{|c|c|c|c|c|c|c|c|c|}
\hline \multirow[t]{2}{*}{ Metaphor Name } & \multicolumn{2}{|c|}{$\begin{array}{c}\text { SHS } \\
(\mathrm{n}=374)\end{array}$} & \multicolumn{2}{|c|}{$\begin{array}{c}\text { AHS } \\
(\mathrm{n}=490)\end{array}$} & \multicolumn{2}{|c|}{$\begin{array}{c}\text { VHS } \\
(\mathrm{n}=218)\end{array}$} & \multicolumn{2}{|c|}{$\begin{array}{l}\text { Total } \\
(\mathrm{n}=1.082)\end{array}$} \\
\hline & $\mathrm{f}$ & $\%$ & $\mathrm{f}$ & $\%$ & $\mathrm{f}$ & $\%$ & $\mathrm{f}$ & $\%$ \\
\hline 1.Kneading dough & 16 & 4.27 & 20 & 4.08 & 12 & 5.50 & 48 & 4.43 \\
\hline 2.Cooking & 14 & 3.74 & 17 & 3.46 & 5 & 2.29 & 36 & 3.32 \\
\hline 3.Constructing & 10 & 2.67 & 12 & 2.44 & 2 & 0.91 & 24 & 2.21 \\
\hline 4. Designing & 7 & 1.87 & 9 & 1.83 & - & - & 16 & 1.47 \\
\hline \multicolumn{9}{|l|}{ Total } \\
\hline Student & 47 & 12.5 & 58 & 11.8 & 19 & 8.7 & 124 & 11.4 \\
\hline Metaphor & 4 & 16 & 4 & 16 & 3 & 12 & 4 & 16 \\
\hline
\end{tabular}

Note. SHS = Science High School, AHS = Anatolian High School, VHS = Vocational High School

In this conceptual category, instruction is seen as a constructive process (e.g., kneading dough, cooking, constructing) which the students see themselves as objects to be knead like a dough, cooked, constructed, and designed. The students generally consider instruction as an activity which shape students. From the standpoint of this conceptual category, instruction is mostly viewed as a traditional way of teaching to students, which is something like knowledge transferred from teachers to students. We can see some extended comments in this conceptual category as follows for exemplars:

Instruction is like kneading dough, because our teachers knead students as dough to make bread (M, AHS).

Instruction is like cooking, because teachers cook delicious meals through instruction ( $F, V H S)$.

Instruction is like constructing, because through instruction teachers build us from bottom to top so as to be a high building ( $M, V H S$ ).

\subsubsection{Instruction as knowledge provider}

The last conceptual category for instruction is "instruction as knowledge provider". There are 249 students $(23 \%)$ and 7 metaphors $(28 \%)$ for instruction as knowledge provider and the following five metaphors are found to be dominant in the study: (1) sun $(7.20 \%)$, (2) teacher $(5.63 \%)$, (3) candle $(4.25 \%)$, (4) light $(2.68 \%)$, and (5) book (1.66\%). Also, 6 metaphors (sun, teacher, candle, light, book, and fountain) are seen to be common amongst all students from the three different high schools in the research (see Table 9). In this conceptual category, SHS and AHS students produced 7 metaphorical images each, whereas VHS students generated 6 metaphorical images. 
Table 9.

Instruction as knowledge provider

\begin{tabular}{|c|c|c|c|c|c|c|c|c|}
\hline \multirow[t]{2}{*}{ Metaphor Name } & \multicolumn{2}{|c|}{$\begin{array}{c}\text { SHS } \\
(\mathrm{n}=374)\end{array}$} & \multicolumn{2}{|c|}{$\begin{array}{c}\text { AHS } \\
(\mathrm{n}=490)\end{array}$} & \multicolumn{2}{|c|}{$\begin{array}{c}\text { VHS } \\
(\mathrm{n}=218)\end{array}$} & \multicolumn{2}{|c|}{$\begin{array}{l}\text { Total } \\
(\mathrm{n}=1.082)\end{array}$} \\
\hline & $\mathrm{f}$ & $\%$ & $\mathrm{f}$ & $\%$ & $\mathrm{f}$ & $\%$ & $\mathrm{f}$ & $\%$ \\
\hline 1.Sun & 27 & 7.21 & 31 & 6.32 & 20 & 9.17 & 78 & 7.20 \\
\hline 2.Teacher & 21 & 5.61 & 24 & 4.89 & 16 & 7.33 & 61 & 5.63 \\
\hline 3.Candle & 17 & 4.54 & 19 & 3.87 & 10 & 4.58 & 46 & 4.25 \\
\hline 4.Light & 13 & 3.47 & 10 & 2.04 & 6 & 2.75 & 29 & 2.68 \\
\hline 5. Book & 9 & 2.40 & 7 & 1.42 & 2 & 0.91 & 18 & 1.66 \\
\hline 6.Fountain & 5 & 1.33 & 3 & 0.61 & 1 & 0.45 & 9 & 0.83 \\
\hline 7.Life & 3 & 0.80 & 5 & 1.02 & - & - & 8 & 0.73 \\
\hline \multicolumn{9}{|l|}{ Total } \\
\hline Student & 95 & 25.4 & 99 & 20.2 & 55 & 25.2 & 249 & 23.0 \\
\hline Metaphor & 7 & 28 & 7 & 28 & 6 & 24 & 7 & 28 \\
\hline
\end{tabular}

Note. SHS = Science High School, AHS = Anatolian High School, VHS = Vocational High School

In this conceptual category, instruction is seen as knowledge provider (e.g., sun, teacher, candle, light) where the students are passive recipients of knowledge. In this regard, instruction is seen both the source and transmitter of knowledge. From the standpoint of this conceptual category, instruction is mostly viewed as a traditional way of teaching to students, which is something like knowledge transferred from teachers to students. We can see some extended comments in this conceptual category as follows for exemplars:

Instruction is like sun, because it warms us with it endless knowledge (M, SHS).

Instruction is like candle, because it light up the darkness (F, AHS).

Instruction is like teacher, because he/she teaches all the things we have to know (F, AHS).

\section{Discussion and Conclusion}

In the present study, we investigated the metaphorical conceptions of high school students about learning and instruction. Although we think that this study has been a simple attempt to understand the metaphorical conceptions about learning and instruction of high school students, we have found several major understandings about these two concepts in the research. The results of this study designed with the purpose of investigating high school students' conceptualizations about learning and instruction using metaphors draw attention to a few important points. In the research, five conceptual themes for learning and four conceptual themes for instruction with their common characteristics may provide a new perspective to understand the notion of learning and instruction from the viewpoints of high school students. This study, as we perceive, can help us to gain a better insight about the concepts of learning and instruction.

First of all, the metaphorical images collected throughout this study about "learning" were grouped under five conceptual categories. Most of the metaphors reflecting the students' images of learning were clustered in the categories of "learning as a basic human need", "learning as a source of knowledge", "learning as a challenging process", and "learning as a cultivating activity". On the other hand, unlike the four dominant conceptual categories we identified, there was one (i.e., learning as a joyful activity) category that was not very popular in the study. Also, the top five dominant metaphors for learning in the study were "book", "tree", "reading", "water", and "teacher". Unlike the five most dominant metaphors, there were also those that were not very popular were "vegetable", "sitting at a café", and "sun". While the conceptual themes of learning represent in some way the teacher-centered approach, the less favored conceptual theme (i.e., learning as a joyful activity) is considered as an extension of learner-centered approach in education. Also, the most dominant metaphors (i.e., book, tree, reading, and teacher) produced for learning concept is believed to represent the teacher-centered approach in education. This means that high school students in this study tended to view learning as the traditional sources of 
knowledge which they get via books, reading, teachers, etc. Thus, it appears from the analysis that high school students consider learning as a way of being filled with knowledge by the traditional ways of schooling. This finding could also mean that many high school students in the Turkish Education System (TES) tend to view learning as a way of getting knowledge from traditional ways of learning rather than contemporary ways of it. This may be due to the fact that high school students were exposed to effects of traditional learning and instruction processes, which in turn, might form their mental images about learning as found in the study. Also, the related finding regarding the learning concept could simply imply an urgent need for high school education in Turkey to review the high school curriculum and adjust it accordingly. Because the high school curriculum, as well as the elementary curriculum in Turkey was revised and updated according to the principles of the constructivist learning approach in 2005-2006 academic year and the findings acquired in the study point out some traditional conceptualizations of students about learning. Unlike the students see learning as a way of creating meaning, they see it as a way of getting information from the traditional resources of learning such as books, teachers, reading, school, etc. A review of the international literature also reveals that there are numerous metaphors for understanding the concept of "learning", each one providing different schemata (e.g., Archer, 1999; Chan, 2000; Dunkin \& Precians, 1992; Eren \& Tekinarslan, 2013; Hadar, 2009; Inbar, 1996; Kalra \& Baveja, 2012; Martinez, Sauleda, \& Huber, 2001; Saban, 2013; Saban, Koçbeker, \& Saban, 2007). For example, in one of these studies, Hadar (2009) identified six conceptions about learning, namely as learning as knowledge increase, learning as memorizing and reproducing, learning as transferring knowledge into the daily life, learning as meaning making, learning as interpretation, and learning as individual development/change. Besides, Eren and Tekinarslan (2013) found two conceptual themes for learning as challenging and explorative process and learning as a basic human need in their study. Also, in studies carried out by Archer (1999), Chan (2000), and Dunkin and Percians (1992), learning was found mostly as a process of receiving of knowledge by the participants. As it is clearly seen from the research literature, there are numerous metaphors for understanding the concept of "learning", each one providing different schemata. Although there are some findings obtained from these studies that resemble the findings acquired in the current research, there are different studies which provide different schemata for learning concept. One of the reasons of this issue could be because "...metaphors are selective. They represent a part, but not the whole, of the phenomena they describe" (Weade \& Ernst, 1990, p. 133). Basically, this emphasizes the fact that a metaphor is the phenomenon and the symbol of itself. If the case was the phenomenon itself, we would not need metaphors to describe something (Yob, 2003, p. 134).

In regard of the metaphorical images collected throughout this study about "instruction" were grouped under four conceptual categories. Most of the metaphors reflecting students' images of instruction were clustered in the categories of "instruction as an art", "instruction as a cultivating facility", "instruction as knowledge provider", and "instruction as a constructive process". On the other hand, unlike the three dominant conceptual categories we identified, there was one category (i.e., instruction as a constructive process) that was not very popular. Unlike the less popular metaphors for instruction, the most popular metaphors seem to represent the teacher-centered approach in education in some way. This means that high school students in this study tended to view instruction as a way of being shaped traditionally. This finding also means that high school students tended to reject the notion of instruction as acting, life and fountain. Thus, it appears from the analysis that high school students consider instruction as a way of shaping students and filling them with information. This may be due to the fact that high school students were exposed to effects of traditional instruction process, which in turn, might form their mental images about instruction as found in the study. Therefore, it can be suggested that the conceptions of high school students about instruction in this study might be affected by their earlier educational experiences in their high school and/or elementary school years. We think that the students participated in this study developed their mental images about the concept of instruction as they were watching their teachers in the classroom at school. Also, the related finding regarding the instruction concept 
could simply imply an urgent need for high school education in Turkey to review the high school curriculum and adjust it accordingly. Because the high school curriculum in Turkey was revised and updated according to the principles of the constructivist learning approach so that teachers are expected to demonstrate contemporary roles such as guiding, designing the learning environment, etc. instead of teaching students the content of school subjects. A review of the related literature also reveals that there are numerous metaphors for understanding the concept of "instruction", each one providing different schemata (e.g., Eren \& Tekinarslan, 2013; Martinez, Sauleda, \& Huber, 2001; Saban, 2003; Saban, Koçbeker, \& Saban, 2006, 2007; Shaw, Barry, \& Mahlios, 2008). For example, the results of the study carried out by Martinez, Sauleda and Huber (2001) indicated that the majority of both experienced and prospective teachers shared traditional metaphors depicting instruction as transmission of knowledge. Similarly, Saban (2003) and Saban, Koçbeker and Saban $(2006,2007)$ found the concept of teacher as knowledge provider and students as passive recipients of knowledge demonstrating that prospective teachers consider instruction as a traditional way of providing students with knowledge. Also, in a study conducted by Eren and Tekinarslan (2013), it was found that prospective teachers conceptualized instruction as an art, as a constructive process, and as a joyful process.

Although there are some findings obtained from these studies that resemble the findings acquired in this research, there are different studies which provide different schemata for instruction concept. The findings that we found in the study suggest that there are some crosscultural similarities in the conceptualization of learning and instruction. Although the studies holding the metaphorical conceptions of learning and instruction were conducted by prospective or in-service teachers in the literature (e.g., Cortazzi \& Jin, 1999; Eren \& Tekinarslan, 2013; Inbar, 1996; Martinez, Sauleda, \& Huber, 2001; Saban, Koçbeker, \& Saban, 2007), a comparison of our findings with those of Bozlk (2002), Eren and Tekinarslan (2013), Inbar (1996), Martinez, Sauleda, and Huber (2001), and Saban, Koçbeker, and Saban (2007) reveal some similarities regarding learning and instruction concepts. These similarities regarding learning and instruction concepts as transmission of knowledge, passive recipient of knowledge, knowledge providing, teachercentered and traditional learning and instruction processes, etc. In most of the studies, we saw that prospective and/or in-service teachers considered learning and instruction processes as getting or gaining knowledge from the traditional sources of schooling. Especially in studies carried out in Turkish context (e.g., Eren \& Tekinarslan, 2013; Saban, 2003; Saban, Koçbeker, \& Saban, 2006, 2007), we found more similar findings which resemble the results we obtained from this research than the findings seen in international literature. In our study, we investigated high school students' metaphorical conceptions about learning and instruction and found similar findings which resemble the results obtained from the research literature. Also, we posit that students watch their teachers in the learning-instruction process in the classroom and conceptualize their images of learning and instruction as they view them in their teachers. There are, of course, other studies that have no similar findings which resemble the results of our study. Therefore, the possible cultural effects in the conceptualizations of learning and instruction are partially supported by our data.

\subsection{Limitations}

We have some limitations in this study, which may provide a meaningful basis for future studies regarding the current concepts. Although we see the sample of the study adequate to investigate high school students' metaphorical conceptions about learning and instruction, future studies through which high school students' metaphors will be investigated based on larger samples may contribute to the understanding of learning and instruction concepts better. We conducted this study on high school students. Therefore, similar studies may be carried out on elementary school students with comparison to high school students. We think that investigating elementary school students' metaphorical conceptions about learning and instruction may contribute to understand the phenomenon better. Readers may have a general perspective from the eyes of high school 
students as well as elementary school students. Besides, we carried out this study in urban high schools in a province of Turkey without taking rural high school students' metaphorical conceptions about learning and instruction into account. Thus, we strongly recommend that researchers should conduct similar studies in order to compare urban and rural high school students' metaphorical conceptions about learning and instruction. Also, we conducted this study in the Turkish context. Hence, similar studies can be carried out in different contexts in comparison with the Turkish one to understand the phenomenon better. Finally, our findings strongly suggest that high school teachers can use metaphor analysis as a means of helping them design better learning environments and examine their educational philosophies and beliefs towards learning and instruction concepts. In this sense, teachers can examine their own concepts of learning and instruction through investigating their students' metaphorical conceptions about these two concepts. On the other hand, the results drawn from this study also reveal that high school teachers should be educated according to the principles of contemporary learning and instruction methods and techniques, because of the students' metaphorical conceptions about learning and instruction were found as having some traditional understandings. Although this study has some limitations, we think that metaphors can serve as a perspective to understand the metaphorical conceptions of students about learning and instruction and help teachers organize and/or design the learning-instruction process in their classrooms.

\subsection{Recommendations}

The research clearly shows that metaphors can be used as a powerful research tool in revealing, understanding and explaining the mental images of students about certain phenomena. The research also shows that teachers can benefit from the metaphors produced by students for learning and instruction in organizing the classroom environment.

In the research, it was seen that students attribute traditional meanings towards learning and instruction. The findings of the research implied that students perceive learning as memorization of knowledge and instruction as a process in which it helps students to memorize knowledge. These results revealed that students perceive learning as knowledge acquisition and instruction as knowledge transfer process, meaning that teachers sustain traditional learning and instruction in a framework where constructivist program reforms are supported. Therefore, it is suggested that teachers should have a role in helping students discover knowledge, rather than adopt the role of transferring knowledge to them.

These results also showed what kind of teaching-learning process teachers carry out in the classroom. The results of the research revealed that teachers maintain a traditional teachinglearning process. Although the research has reported that teachers generally state that they adopt a contemporary teaching-learning process, the metaphors students put forward for learning and instruction show the exact opposite of this situation. The results implied that teachers are far from designing a constructivist learning environment. In this respect, it is important that teachers should receive in-service training on classroom learning and instruction. However, subjecting teachers to such training alone may be far from changing their learning and instruction. Especially, it is considered that educational beliefs of teachers have important effects on the findings obtained.

Acknowledgements. This paper was presented at International Congress on Education for the Future: Issues and Challenges (May, 2015), held in Ankara University, Ankara, Turkey.

\section{References}

Anglin, L. W., \& Dugan, T. (1982, March). Teachers' perceptions of existing and ideal school curriculum: An analysis of metaphors. Paper presented at the Annual Meeting of the American Educational Research Association, New York.

Archer, J. (1999, November). Teachers' beliefs about successful teaching and learning. Paper presented at the AARENZARE Conference, Melbourne. 
Aykaç, N., \& Çelik, Ö. (2014). Öğretmenlerin ve öğretmen adaylarının eğitim programına ilişkin metaforik algılarının karşılaştırılması. Eğitim ve Bilim, 39(173), 328-340.

Bozlk, M. (2002). The college student as learner: Insight gained through metaphor analysis. College Student Journal, 36, 142-151.

Chan, K. (2000, December). Teacher education students' epistemological beliefs: A cultural perspective on learning and teaching. Paper presented at the Australian Association for Research in Education Conference, Sydney.

Creswell, J. W. (2012). Educational research: Planning, conducting and evaluating quantitative and qualitative research (4th ed.). Upper Saddle River, New Jersey: Merrill-Prentice Hall.

Cortazzi, M., \& Jin, L. (1999). Bridges to learning: Metaphors of teaching, learning and language. In L. Cameron \& G. Low (Eds.), Researching and applying metaphor (pp. 149-176). Cambridge: Cambridge University Press.

Creswell, J. W. (1998). Qualitative inquiry and research design: Choosing among five traditions. Thousand Oaks, CA: Sage.

Dunkin, M. J., \& Precians, R. P. (1992). Award-winning university teachers' concept of teaching. Higher Education, 24, 483-502.

Eren, A., \& Tekinarslan, E. (2013). Prospective teachers' metaphors: Teacher, teaching, learning, instructional material and evaluation concepts. International Journal of Social Science and Education, 3(2), 435-445.

Fraenkel, J. R., \& Wallen, N. E. (2009). How to design and evaluate research in education (7th ed.). New York: McGraw-Hill.

Gültekin, M. (2013). The metaphors that primary education teacher candidates use regarding curriculum. Education and Science, 38(169), 126-141.

Güner, N. (2012). Using metaphor analysis to explore high school students' attitudes towards learning mathematics. Education, 133, 39-48.

Hadar, L. (2009). Ideal versus school learning: Analyzing Israeli secondary school students' conceptions of learning. International Journal of Educational Research, 48, 1-11.

Inbar, D. (1996). The free educational prison: Metaphors and images. Educational Research, 38(1), 77-92.

Kalra, M. B., \& Baveja, B. (2012). Teacher thinking about knowledge, learning and learners: A metaphor analysis. Procedia-Social and Behavioral Sciences, 55, 317-326.

Krippendorf, K. (1980). Content analysis: An introduction to its methodology. Beverly Hills, CA: Sage.

Mahlios, M., Massengill-Shaw, D., \& Barry, A. (2010). Making sense of teaching through metaphors: A review across three studies. Teachers and Teaching: Theory and Practice, 16(1), 49-71.

Martinez, M. A., Sauleda, N., \& Huber, G. L. (2001). Metaphors as blueprints of thinking about teaching and learning. Teaching and Teacher Education, 17, 965-977.

Memnun, D. S. (2015). Secondary school students' metaphors about mathematical problem and change of metaphors according to grade level. Necatibey Faculty of Education Electronic Journal of Science and Mathematics Education, 9(1), 351-374.

Merriam, S. B. (1998). Qualitative research and case study applications in education. San Francisco: Jossey-Bass.

Miles, M., \& Huberman, M. (1994). Qualitative data analysis: An expanded source book (2nd ed.). Thousand Oaks, CA: Sage.

Moser, K. S. (2000). Metaphor analysis in psychology: Method, theory, and fields of application. Forum: Qualitative Social Research, 1(2), Available from http://www.qualitative-research.net/fqs-texte/2-00/200moser-e.htm.

Mouraz, A., Pereira, A., \& Monteiro, R. (2013). The use of metaphors in the processes of teaching and learning in higher education. International Online Journal of Educational Sciences, 5(1), 99-110.

Oxford, R. L., Tomlinson, S., Barcelos, A., Harrington, C., Lavine, R. Z., \& Saleh, A. (1998). Clashing metaphors about classroom teachers: Toward a systematic typology for the language teaching field. System, 26, 3-50.

Patton, M. Q. (1990). Qualitative evaluation and research methods (2nd ed.). Newbury Park, CA: Sage.

Saban, A. (2013). Prospective primary teachers' metaphorical images of learning. Journal of Teaching and Education, 2(1), 195-202.

Saban, A. (2010). Prospective teachers' metaphorical conceptualizations of learner. Teaching and Teacher Education, 26, 290-305.

Saban, A., Koçbeker, B. N., \& Saban, A. (2007). Prospective teachers' conceptions of teaching and learning revealed through metaphor analysis. Learning and Instruction, 17(2), 123-139. 
Saban, A. (2006). Functions of metaphor in teaching and teacher education: A review essay. Teaching Education, 17(4), 299-315.

Saban, A., Koçbeker, B. N., \& Saban, A. (2006). An investigation of the concept of teacher among prospective teachers through metaphor analysis. Educational Sciences: Theory \& Practice, 6(2), 509-522.

Saban, A. (2004). Giriş düzeyindeki sınıf öğretmeni adaylarının öğretmen kavramına ilişkin ileri sürdükleri metaforlar. Türk Ĕ̆itim Bilimleri Dergisi, 2, 135-155.

Saban, A. (2003). A Turkish profile of prospective elementary school teachers and their views of teaching. Teaching and Teacher Education, 19, 829-846.

Sevindik, F., Memnun, D. S., \& Çenberci, S. (2016). Metaphors about mathematics of industrial vocational high school students. Journal of Educational and Instructional Studies in the World, 6(1), 13-21.

Shaw, D. M., Barry, A., \& Mahlios, M. (2008). Pre-service teachers' metaphors of teaching in relation to literacy beliefs. Teachers and Teaching, 14, 35-50.

Turkish Statistical Institution [TurkStat] (2013). Nigde 2013 with some selected indicators. Available from http://www.tuik.gov.tr/.../iller/NIGDE.pdf

Turhan-Türkkan, B., \& Yeşilpınar-Uyar, M. (2016). Metaphors of secondary school students towards the concept of "mathematical problem". Çukurova Üniversitesi Eğitim Fakültesi Dergisi, 45(1), 99-130.

Weade, R., \& Ernst, G. (1990). Pictures of life in classrooms and the search for metaphors to frame them. Theory into Practice, 29(2), 133-140.

Yob, I. M. (2003). Thinking constructively with metaphors. Studies in Philosophy and Education, 22, 127-138.

Zeteroğlu, E. Ş., Doğan, Y., \& Derman, M. T. (2012). Determining the opinions of preschool and primary school teacher candidates on creativity and metaphorical perception. Educational Sciences: Theory and Practice, 12(4), 3135-3152. 